\title{
Reconsideration of biallelic inactivation of the $V H L$ tumour suppressor gene in hemangioblastomas of the central nervous system
}

S Gläsker, B U Bender, T W Apel, V van Velthoven, L M Mulligan, J Zentner, H P H Neumann

Department of Nephrology and Hypertension, Albert-LudwigsUniversity, Medizinische Universitätsklinik, Hugstetter Straße 55, D 79106 Freiburg, Germany

S Gläsker

B U Bender

T W Apel

H P H Neumann

Department of Neurosurgery $\mathrm{V}$ van Velthoven J Zentner

Department of Pediatrics, Queen's University, Kingston, Ontario, Canada

L M Mulligan

Correspondence to: Professor H P H Neumann Neumann@ mm41.ukl-freiburg.de

Received 28 July 2000 and in revised form

22 December 2000

Accepted 5 January 2001

\begin{abstract}
Objectives-Cerebellar haemangioblastoma occurs sporadically or as a component tumour of autosomal dominant von Hippel-Lindau disease. Biallelic inactivation of the $V H L$ tumour suppressor gene, which is located on chromosome $3 p$, has been shown to be involved in the pathogenesis of both tumour entities. Mechanisms of $V H L$ inactivation are intragenic mutations, mitotic recombination events, and hypermethylation of the promoter region. The systematic and complete examination of these genetic and epigenetic phenomena in large series of von Hippel-Lindau disease related and sporadic hemangioblastomas has, thus far, not been performed.

Methods-In the largest series to date, 29 von Hippel-Lindau disease associated and 13 sporadic haemangioblastomas were investigated for all suggested inactivating mechanisms of the $V H L$ gene using single strand conformational polymorphism (SSCP), loss of heterozygosity (LOH), and methylation analyses. Additionally, corresponding blood samples of all patients were screened for $V H L$ germline mutations by SSCP and Southern blotting.

Results-Germline mutations were identified in $94 \%$ of patients with von HippelLindau disease and their tumours and $62 \%$ of these hemangioblastomas showed LOH of chromosome $3 \mathrm{p}$. Of the 13 sporadic tumours, $23 \%$ showed a single somatic mutation of the $V H L$ gene that was not present in the germline. 3 p LOH was identified in $50 \%$ of informative sporadic tumours. No von Hippel-Lindau disease related or sporadic tumour demonstrated $V H L$ promoter hypermethylation.

Conclusions-For most von Hippel-Lindau disease related haemangioblastomas, the inactivation or loss of both alleles of the $V H L$ gene, as predicted by the Knudson two hit theory, is required. However, in a subset of tumours including most sporadic haemangioblastomas, the genetic pathways involved in tumorigenesis have yet to be defined and may represent alterations of a different pathway or pathways. (F Neurol Neurosurg Psychiatry 2001;70:644-648)
\end{abstract}

Keywords: hemangioblastoma; von Hippel-Lindau disease; tumour suppressor gene; DNA methylation
Haemangioblastomas are benign and usually cystic tumours which are predominantly found in the cerebellum of adults. They occur as a sporadic entity or as part of von Hippel-Lindau disease, an autosomal dominant disorder which is characterised by CNS haemangioblastomas and, in addition, by retinal angiomas, renal cell carcinomas, and pheochromocytomas. ${ }^{1}$

The VHL susceptibility tumour suppressor gene maps to $3 \mathrm{p} 25-26$ and was identified in 1993. ${ }^{2}$ The three exons contain a coding sequence of 852 nucleotides. Germline mutations within the VHL gene have been identified in up to $100 \%$ of affected families. ${ }^{3}$ Suggested functions of the VHL gene are (1) down regulation of hypoxia inducible mRNAs${ }^{4}$; (2) proper assembly of the extracellular fibronectin matrix $^{5}$; (3) regulation of exit from the cell cycle $^{6}$ and (4) regulation of expression of carbonic anhydrases 9 and $12 .{ }^{7}$ The VHL gene seems to be a classic tumour suppressor gene with biallelic inactivation by two genetic alterations. In von Hippel-Lindau disease, the first hit is an inherited germline mutation which is present in one allele in each cell of the body. It is often a "small" intragenic mutation. The second hit is a somatic DNA alteration which is acquired during the patient's lifetime and is present only in the tumour tissue. Known somatic inactivating mechanisms include recombination events resulting in a loss of heterozygosity (LOH) of the VHL gene, and to a lesser extent intragenic point mutations. Recently, hypermethylation of normally unmethylated sites of the promoter that are rich in 5'-CG-3' dinucleotides, so called CpG islands, has been suggested as an epigenetic mechanism of tumour suppressor gene inactivation. ${ }^{8}$ Genomewide changes in methylation pattern are known to occur in all forms of neoplasia. Although non-island CpGs become hypomethylated, certain $\mathrm{CpG}$ islands become densely hypermethylated. Furthermore, in normal tissues, extensive methylation of promoter region $\mathrm{CpG}$ islands is associated with transcriptional silencing. This is well known for imprinted alleles and genes on the inactive $\mathrm{X}$ chromosome. ${ }^{9}$ The role of tumour suppressor gene hypermethylation, however, is still unclear in many tumours.

Previous genetic studies on CNS haemangioblastomas either did not analyse both von Hippel-Lindau disease related and sporadic tumours or did not investigate all known mechanisms of gene inactivation. These studies have yielded a broad range of different 
results ${ }^{10-16}$ which may be a consequence of the investigation of only small series.

To get a more complete and reliable picture of $V H L$ gene function in haemangioblastoma pathogenesis, we sought to examine and compare an extensive series of 29 von HippelLindau disease associated and 13 sporadic hemangioblastomas for all suggested mechanisms of $V H L$ inactivation.

\section{Methods}

PATIENTS AND TUMOUR SAMPLES

A total of 42 CNS haemangioblastoma samples were obtained from 31 patients, who were consecutively treated between 1993 and 1997 at the Department of Neurosurgery of the Freiburg University Medical Centre. The series comprised 29 von Hippel-Lindau disease associated tumours obtained from 18 patients with the disease and 13 sporadic tumours, which were obtained from 13 patients with no clinical signs of a tumour syndrome. Eighty three per cent of disease associated and $62 \%$ of sporadic tumours were located in the cerebellum. The diagnosis of von Hippel-Lindau disease was established by the criteria of Neumann et $a l^{17}$ The tumours were from 11 male and 20 female patients. The age at operation ranged from 16 to 71 years with an average of 38 years. The tumour samples were snap frozen in liquid nitrogen and were stored at $-80^{\circ} \mathrm{C}$ until the molecular genetic investigations were performed. All tumours were classified histopathologically according to the World Health Organisation classification. ${ }^{18}$

For germ line analysis blood samples were available from all patients. Our study was approved by the ethics committee of the University of Freiburg and our patients gave informed consent.

MOLECULAR GENETIC ANALYSES

Genomic and tumour DNA was isolated by standard methods. ${ }^{19}$ Southern blotting was performed to detect large deletions in the $V H L$ gene. Genomic DNA $(7 \mu \mathrm{g})$ was digested with excess Eco RI (Boehringer Mannheim). The fragments were separated in a $0.6 \%$ agarose gel with $1 \times \mathrm{TBE}$ buffer and transferred to a positively charged nylon membrane (Boehringer Mannheim) by capillary blot. Fragments were visualised with the DIG high prime labelling and detection starter kit I (Boehringer Mannheim) according to the supplier. The probes for hybridisation of the Southern blot were made by two sets of primers, one in the very beginning of exon 1 and another set in the 3 ' untranslated region of exon 3 .

Single strand conformation polymorphism (SSCP) analysis was used to find point mutations, small deletions, or insertions. Four sets of primers were needed to cover all three exons. Mixtures contained $100 \mathrm{ng}$ genomic DNA, $0.2 \mathrm{mM}$ dNTP, $0.5 \mathrm{pmol} / \mu \mathrm{l}$ of each primer, $\mathrm{MgCl}_{2}$ and $0.1 \mathrm{U} / \mu \mathrm{l}$ Taq DNA polymerase (Gibco BRL). Polymerase chain reaction (PCR) conditions and sets of primers have been previously described. ${ }^{20}$ Polymerase chain reaction amplified fragments $(10 \mu \mathrm{l})$ were denatured by adding $15 \mu \mathrm{l}$ denaturing solution (containing 95\% formamide, $10 \mathrm{mM} \mathrm{NaOH}$, $0.05 \%$ xylene cyanol, $0.05 \%$ bromophenol blue) and heating to $96^{\circ} \mathrm{C}$ for 3 minutes before chilling on ice. Denatured fragments were separated on a polyacrylamide gel $\left(\mathrm{MDE}^{\mathrm{TM}}\right.$ Gel Solution, FMC Bioproducts Europe) with $0.5 \times \mathrm{MDE}$ and $0.6 \times \mathrm{TBE}$ buffer according to the manufacturer. After separation at $200 \mathrm{~V}$ for 16 hours the fragments were stained with silver according to established protocols. ${ }^{21}$ Aberrant bands were cut out of the gel, dissolved in water, and reamplified for sequencing, which was performed with nested fluorescence labelled primers using the dideoxy method and a semiautomatic sequencer (Alf, Pharmacia). All mutations were confirmed by sequencing. Thus we newly detected or reconfirmed germline mutations as previously described in a larger series of our patients. ${ }^{22}$

Altogether, three polymorphic markers on chromosome $3 p$ were used for the $\mathrm{LOH}$ analysis of the $V H L$ gene including one dinucleotide repeat polymorphism (D3S1038), which is located close to the VHL locus at $3 \mathrm{p} 25-26,{ }^{23}$ and two restriction fragment length polymorphism (RFLP) markers, which are located directly within the VHL gene: One Hae III RFLP marker is located at the nucleotide 19 of the VHL gene, ${ }^{28}$ the other one is a PCR generated Acc I RFLP marker, which is located at nucleotide 1149 in the 3 ' untranslated region of VHL. ${ }^{24}$

For investigation of $V H L$ promoter hypermethylation, we performed a PCR based technique using the methylation sensitive enzyme Ehe I, which has two recognition sites within the CpG island of the VHL promoter: Genomic DNA $(1 \mu \mathrm{g})$ was digested with $10 \mathrm{U}$ Ehe I (MBI Fermentas) and buffer $\mathrm{Y}^{+} /$Tango $^{\mathrm{TM}}$ in a total volume of $150 \mu \mathrm{l}$ at $37^{\circ} \mathrm{C}$ for 16 hours. Ehe I has the recognition sequence 5'-GGCGCC-3' within exon 1 and will not cleave if the internal cytosine is methylated. To ensure complete digestion, a further $5 \mathrm{U}$ Ehe I was added after digestion and the sample was incubated for another hour at $37^{\circ} \mathrm{C}$. Before the PCR was performed, the sample was purified with GeneClean II DNA purification Kit (Bio 101) according to the supplier's instructions. The digested DNA was redissolved in $20 \mu \mathrm{l}$ TrisEDTA-buffer. Two microlitres were used for the following $15 \mu \mathrm{l}$ multiplex PCR. One set of primers flanked the Ehe I sites within exon 1 (F:5'-GAG GCA GGC GTC GAA GAG TAC GGC-3', R: 5'-GAC TGC GAT TGC AGA AGA TGA CCT-3' and will only amplify in cases where Ehe I did not cleave- that is, in the presence of $V H L$ gene methylation. As a control for failure of the PCR, a second pair of primers was used (F: 5'-CTG AGA CCC TAG TCT GCC ACT GAG-3' R: 5'-CAA AAG CTG AGA TGA AAC AGT GTA-3') to amplify exon 3, which has no Ehe I restriction site. The reaction volumes contained $2 \mu \mathrm{M}$ primers, $0.2 \mathrm{mM}$ dNTPs, and 0.5 U Taq polymerase (GIBCO BRL). Fragments were amplified for 27 cycles of 30 seconds at $95^{\circ} \mathrm{C}, 40$ seconds at $62^{\circ} \mathrm{C}$, and 30 seconds at $72^{\circ} \mathrm{C}$. As a second control, the same procedure was carried out for each DNA sample 
without enzyme to ensure correct amplification of exon 1.

\section{Results}

All CNS haemangioblastomas were investigated for alterations of the VHL gene by SSCP, $\mathrm{LOH}$, and methylation analyses. Additionally, corresponding blood samples of all von HippelLindau disease and sporadic patients were screened for VHL gene mutations by SSCP and Southern blot analysis. The results are listed in table 1 .

Analysis of the blood samples by SSCP disclosed abnormal electrophoretic patterns in the germline of 14 out of 18 patients with von Hippel-Lindau disease. Subsequent sequencing showed that 10 patients had missense mutations, two had in frame insertions, and one had a nonsense mutation. In one patient (9), no mutation could be detected by sequencing, although the SSCP electrophoretic pattern was abnormal. The results of sequencing are summarised in table 1 . Southern blot analysis of the germline DNA disclosed deletions of $2 \mathrm{~kb}$ within the VHL gene in four patients with von Hippel-Lindau disease, who had no SSCP aberrations. Thus, a germline mutation was identified in 17 of 18 (94\%) patients with the disease.

All disease related tumours showed the same mutation as the corresponding blood sample and no disease related tumour showed a somatic mutation in addition to the germline mutation. Three of the 13 sporadic tumours had a single somatic mutation including one nonsense and two frameshift mutations (table 1). The nonsense mutation (R161X) in the sporadic tumour 28 has been described before as a germline mutation. ${ }^{25}$ The two other mutations have not been described so far.

The results of the LOH analysis are summarised in figure 1. Allelic losses on chromosome $3 p$ were found in 13 of 21 informative von Hippel-Lindau disease tumours $(62 \%)$ and in

Table 1 Mutations of the VHL gene in VHL related and sporadic haemangioblastomas of the CNS. 42 tumours from 31 patients were investigated

\begin{tabular}{|c|c|c|c|c|c|c|}
\hline \multirow[b]{2}{*}{ Tumour No } & \multirow[b]{2}{*}{ Tumour location } & \multicolumn{3}{|l|}{ Germline mutation } & \multicolumn{2}{|c|}{ Somatic mutation } \\
\hline & & Nucleotide & $A A$ & Mutation type & $\mathrm{LOH}$ & Methylation \\
\hline \multicolumn{7}{|c|}{$V H L$ related tumours $(n=29$ investigated $):$} \\
\hline 1a & Cerebellum & $446 \mathrm{~A} / \mathrm{G}$ & N78S & Missense & $\mathrm{LOH}$ & Negative \\
\hline $1 \mathrm{~b}$ & Cerebellum & $446 \mathrm{~A} / \mathrm{G}$ & N78S & Missense & $\mathrm{LOH}$ & Negative \\
\hline $1 \mathrm{c}$ & Cerebellum & $446 \mathrm{~A} / \mathrm{G}$ & N78S & Missense & $\mathrm{LOH}$ & Negative \\
\hline 2 & Cerebellum & $746 \mathrm{~T} / \mathrm{A}$ & L178P & Missense & $\mathrm{LOH}$ & Negative \\
\hline $3 a$ & Cerebellum & $699 \mathrm{C} / \mathrm{G}$ & $\mathrm{C} 162 \mathrm{~W}$ & Missense & Negative & Negative \\
\hline $3 b$ & Cerebellum & $699 \mathrm{C} / \mathrm{G}$ & $\mathrm{C} 162 \mathrm{~W}$ & Missense & $\mathrm{LOH}$ & Negative \\
\hline 4 & Cerebellum & $479 \mathrm{~T} / \mathrm{C}$ & L89P & Missense & NI & Negative \\
\hline $5 a$ & Cerebellum & $761 \mathrm{C} / \mathrm{A}$ & S183X & Nonsense & NI & Negative \\
\hline $5 b$ & Cerebellum & $761 \mathrm{C} / \mathrm{A}$ & S183X & Nonsense & NI & Negative \\
\hline 6 & Cerebellum & $2 \mathrm{~kb}$ del & & Deletion & $\mathrm{LOH}$ & Negative \\
\hline $7 \mathrm{a}$ & Cerebellum & $2 \mathrm{~kb}$ del & & Deletion & $\mathrm{LOH}$ & Negative \\
\hline $7 \mathrm{~b}$ & Spine T8/9 & $2 \mathrm{~kb}$ del & & Deletion & $\mathrm{LOH}$ & Negative \\
\hline $8 \mathrm{a}$ & Cerebellum & 443 ins TCT & 77insL & In frame insertion & Negative & Negative \\
\hline $8 \mathrm{~b}$ & Cerebellum & 443 ins TCT & 77 insL & In frame insertion & Negative & Negative \\
\hline $8 \mathrm{c}$ & Cerebellum & 443 ins TCT & 77 insL & In frame insertion & Negative & Negative \\
\hline $8 \mathrm{~d}$ & Cerebellum & 443 ins TCT & 77 insL & In frame insertion & Negative & Negative \\
\hline 9 & Spine C4/5 & Not detected & & & Negative & Negative \\
\hline 10 & Cerebellum & $479 \mathrm{~T} / \mathrm{C}$ & L89P & Missense & NI & Negative \\
\hline 11 & Cerebellum & $505 \mathrm{~T} / \mathrm{C}$ & $\mathrm{Y} 98 \mathrm{H}$ & Missense & NI & Negative \\
\hline 12 & Vermis & $665 \mathrm{~T} / \mathrm{C}$ & I151T & Missense & $\mathrm{LOH}$ & Negative \\
\hline 13 & Cerebellum & $505 \mathrm{~T} / \mathrm{C}$ & $\mathrm{Y} 98 \mathrm{H}$ & Missense & Negative & Negative \\
\hline $14 \mathrm{a}$ & Cerebellum & Partial deletion ${ }^{\star}$ & & Deletion & NI & Negative \\
\hline $14 \mathrm{~b}$ & Cerebellum & Partial deletion ${ }^{\star}$ & & Deletion & NI & Negative \\
\hline 15 & Cerebellum & 529 ins GCC & 106insR & In frame insertion & NI & Negative \\
\hline 16 & Cerebellum & $2 \mathrm{~kb}$ del & & Deletion & $\mathrm{LOH}$ & Negative \\
\hline $17 \mathrm{a}$ & Med. obl. & $505 \mathrm{~T} / \mathrm{C}$ & $\mathrm{Y9} 9 \mathrm{H}$ & Missense & $\mathrm{LOH}$ & Negative \\
\hline $17 \mathrm{~b}$ & Spine C8 & $505 \mathrm{~T} / \mathrm{C}$ & Y98H & Missense & Negative & Negative \\
\hline $18 \mathrm{a}$ & Cerebellum & $475 \mathrm{~T} / \mathrm{A}$ & W88R & Missense & $\mathrm{LOH}$ & Negative \\
\hline \multirow[t]{2}{*}{$18 \mathrm{~b}$} & Spine T7/8 & $475 \mathrm{~T} / \mathrm{A}$ & W88R & Missense & $\mathrm{LOH}$ & Negative \\
\hline & & & & \multicolumn{3}{|l|}{ Somatic mutation } \\
\hline Tumour No & Tumour location & Germline mutation & & $S S C P$ & $\mathrm{LOH}$ & Methylation \\
\hline \multicolumn{7}{|c|}{ Sporadic tumours ( $n=13$ investigated): } \\
\hline 19 & Cerebellum & Not detected & & Not detected & $\mathrm{LOH}$ & Negative \\
\hline 20 & Cerebellum & Not detected & & Not detected & Negative & Negative \\
\hline 21 & Med. obl. & Not detected & & 612 del TG frameshift & Negative & Negative \\
\hline 22 & Cerebellum & Not detected & & Not detected & Negative & Negative \\
\hline 23 & Med. obl. & Not detected & & Not detected & $\mathrm{LOH}$ & Negative \\
\hline 24 & Cerebellum & Not detected & & Not detected & Negative & Negative \\
\hline 25 & Cerebellum & Not detected & & Not detected & $\mathrm{LOH}$ & Negative \\
\hline 26 & Med obl & Not detected & & Not detected & NI & Negative \\
\hline 27 & Cerebellum & Not detected & & Not detected & NI & Negative \\
\hline 28 & Spine, $\mathrm{C} 1 / 2$ & Not detected & & $694 \mathrm{C} / \mathrm{T}$ R161X & Negative & Negative \\
\hline 29 & Cerebellum & Not detected & & 681 ins $11 \mathrm{bp}$ frameshift & $\mathrm{LOH}$ & Negative \\
\hline 30 & Spine, T11 & Not detected & & Not detected & NI & Negative \\
\hline 31 & Cerebellum & Not detected & & Not detected & $\mathrm{LOH}$ & Negative \\
\hline
\end{tabular}

LOH=Loss of heterozygosity; NI=Not informative for LOH analysis; Med obl=medulla oblongata.

${ }^{\star}$ Result with kind permission of Dr Stolle, Department of Medical Genetics, University of Pennsylvania. Some of the listed germline mutations were detected in collaboration with Dr Brauch and coworkers. ${ }^{28}$ Patients 4 and 10 had the same mutation $479 \mathrm{~T} / \mathrm{C}$ and were related. Furthermore the patients with the mutation $505 \mathrm{~T} / \mathrm{C}$ (patients 11, 13, and 17) were related. All other patients were Not related. 
Chromosome 3p

\begin{tabular}{|c|c|c|c|c|c|c|c|}
\hline \multicolumn{4}{|c|}{ Familial tumours } & \multicolumn{4}{|c|}{ Familial tumours } \\
\hline Tumour & D3S1038 & VHL19 & VHL1149 & Tumour & D3S1038 & VHL19 & VHL1149 \\
\hline $1 a$ & $\square$ & $\square$ & $\square$ & $14 b$ & $\square$ & $\square$ & $\square$ \\
\hline $1 \mathrm{~b}$ & - & $\square$ & $\square$ & 15 & $\square$ & $\square$ & $\square$ \\
\hline $1 \mathrm{c}$ & a & $\square$ & $\square$ & 16 & $\overline{\mathbf{a}}$ & $\square$ & - \\
\hline 2 & 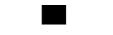 & a & a & $17 a$ & a & $\overline{\mathbf{a}}$ & $\overline{\mathbf{a}}$ \\
\hline $3 a$ & $\square$ & $\square$ & $\square$ & $17 b$ & $\square$ & $\square$ & $\square$ \\
\hline $3 b$ & $\square$ & $\square$ & [ & $18 a$ & ש & 口 & 口 \\
\hline 4 & $\square$ & $\square$ & $\square$ & $18 b$ & $\square$ & a & $\square$ \\
\hline $\begin{array}{l}5 a \\
5 b\end{array}$ & $\square$ & $\square$ & $\square$ & \multicolumn{4}{|c|}{ Sporadic tumours } \\
\hline 6 & $\square$ & $\square$ & $\square$ & \begin{tabular}{|l|}
19 \\
19
\end{tabular} & 口 & $\square$ & $\square$ \\
\hline $7 a$ & $\square$ & ש & $\square$ & 20 & $\square$ & $\square$ & $\square$ \\
\hline $7 b$ & $\square$ & a & $\square$ & 21 & $\square$ & $\square$ & $\square$ \\
\hline $8 a$ & $\square$ & $\square$ & $\square$ & 22 & $\square$ & $\square$ & $\square$ \\
\hline $8 b$ & $\square$ & $\square$ & $\square$ & 23 & च & 口 & च \\
\hline $8 c$ & $\square$ & $\square$ & $\square$ & 24 & $\square$ & $\square$ & $\square$ \\
\hline $8 d$ & $\square$ & $\square$ & $\square$ & 25 & घ & $\square$ & $\square$ \\
\hline 9 & $\square$ & $\square$ & $\square$ & 26 & $\square$ & $\square$ & $\square$ \\
\hline 10 & $\square$ & $\square$ & $\square$ & 27 & $\square$ & $\square$ & $\square$ \\
\hline 11 & $\square$ & $\square$ & $\square$ & 28 & $\square$ & $\square$ & $\square$ \\
\hline 12 & 口 & $\square$ & $\square$ & 29 & 口 & $\square$ & $\square$ \\
\hline 13 & $\square$ & $\square$ & $\square$ & 20 & $\square$ & $\square$ & $\square$ \\
\hline $14 a$ & $\square$ & $\square$ & $\square$ & 31 & $\square$ & 口 & $\square$ \\
\hline
\end{tabular}

Figure 1 Results of LOH investigations in VHL and sporadic haemangioblastomas. Three different loci on chromosome 3p were investigated. A PCR generated Acc I RFLP at nt 1149 and a Hae III RFLP at nt $19^{28}$ were located within the VHL gene, mapped to 3p25-26. The third one was a dinucleotide repeat polymorphism, D3S1038, located at $3 p 25 .{ }^{23}$ Black squares $=L O H$; open squares=retained heterozygosity; grey squares =not informative.
VHL associated

haemangioblasoma

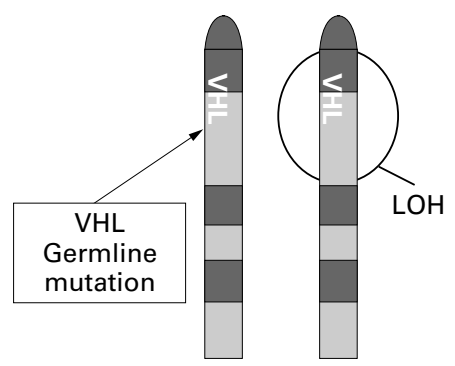

1st Allele 2nd Allele
Sporadic

haemangioblastoma

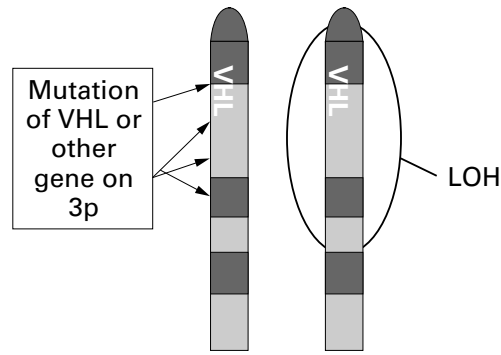

1st Allele 2nd Allele
Figure 2 Haemangioblastoma associated with von Hippel-Lindau disease and sporadic hemangioblastoma.
The methylation analysis did not show hypermethylation of the VHL gene promoter region in any of the investigated tumours. This was indicated by failure of amplification of the promoter fragment in all tumour and blood samples that were digested with Ehe I. All undigested samples amplified correctly and the exon 3 control fragment also amplified in each case.

\section{Discussion}

Previous reports on mutation analysis of the VHL gene in von Hippel-Lindau disease related and sporadic CNS haemangioblastomas have yielded a broad range of different results. ${ }^{10-16}$ This phenomenon might be the consequence of only a few cases in the investigated series and the incomplete analysis of VHL gene inactivating mechanisms. Here we have systematically and rigorously investigated the VHL gene for all known inactivating mechanisms in the largest study to date.

Reported frequencies of $\mathrm{LOH}$ on chromosome $3 \mathrm{p}$ in disease related haemangioblastomas are $14 \%(1 / 7),{ }^{15} 27 \%(3 / 11),{ }^{16} 66 \%(2 / 3),{ }^{12}$ and $100 \%(4 / 4)^{13}$ with an average of $40 \%$. Our investigations showed $3 \mathrm{p} \mathrm{LOH}$ in 13 of 21 informative von Hippel-Lindau disease tumours $(62 \%)$, indicating that a classic two hit inactivation of the VHL gene is a common mechanism in disease associated haemangioblastomas (fig 2). In our sporadic tumours we detected $\mathrm{LOH}$ of the telomeric $3 \mathrm{p}$ region in $50 \%$ of cases. These results are in good agreement with two previous studies, which have found allelic loss on $3 p$ in $1 / 2^{12}$ and $10 / 19^{14}$ sporadic CNS haemangioblastomas.

Previous investigations on hypermethylation of the VHL gene in CNS haemangioblastomas have yielded different results and were based on small series. Prowse et al found hypermethylation in four of eight investigated von Hippel-Lindau disease related CNS haemangioblastomas. ${ }^{16}$ By contrast, Tse et al investigated eight (three disease associated and five sporadic) haemangioblastomas and did not detect hypermethylation of the VHL gene in any of the tumours. ${ }^{12}$ In agreement with the second study we could not find any hypermethylation of the VHL gene promoter region. Both previous groups used methods that were similar to ours, which is digestion with a methylation sensitive restriction enzyme and subsequent PCR with flanking primers. However, the particular enzymes used were different (Sma I and NotI I versus Ehe I in our study). The different results can eventually be explained by different levels of sensitivity. Quantitative analyses of methylation might help to clarify this controversial issue.

With our SSCP method, which has been shown to have a sensitivity of $86 \%$ in detecting VHL germline mutations ${ }^{26}$ we have found only three somatic VHL gene mutations, all of which occurred in sporadic haemangioblastomas. Only one of these tumours showed biallelic VHL gene inactivation due to an additional $\mathrm{LOH}$ of the $V H L$ gene region at $3 \mathrm{p}$. The relatively low frequencies of somatic $V H L$ gene mutations in sporadic hemangioblastomas and 
biallelic VHL gene inactivation agree with three previous studies, in which somatic mutations have been reported with an average of $18 \%$ (7/38). ${ }^{10-12} 14$ In previous studies, no sporadic tumour has been shown to have biallelic VHL gene inactivation, as these studies did not investigate all inactivating mechanisms, or the tumours retained heterozygosity. By contrast, our investigation of all known $V H L$ gene inactivating mechanisms is now highly suggestive that biallelic $V H L$ gene inactivation is not a common mechanism in the tumorigenesis of sporadic CNS haemangioblastoma. This is very interesting, as until now, the "classic" Knudson two hit mechanism was viewed as dogma for the VHL gene in both von Hippel-Lindau disease associated and sporadic haemangioblastoma..$^{101114}$ Furthermore, the fact that five of 10 sporadic tumours showed $3 p$ $\mathrm{LOH}$, but four of them lacked structural $V H L$ gene alterations implies that the VHL gene plays a minor role in the sporadic tumours and that there are other genes on chromosome $3 p$ with involvement in haemangioblastoma tumorigenesis. This has already been suggested for clear cell renal cancer, where mutations in tumour suppressor genes at $3 \mathrm{p} 14-\mathrm{p} 21$ seem to have a primary role in tumorigenesis in tumours with $3 \mathrm{p} \mathrm{LOH}$ but without VHL gene inactivation. ${ }^{27}$

In summary, our data suggest that the genetic pathways involved in pathogenesis in von Hippel-Lindau disease haemangioblastoma versus sporadic haemangioblastoma are distinct. Further investigations on chromosome $3 p$ in CNS haemangioblastomas might clarify this hypothesis further.

This work was supported by a grant from the Centre of Clinical Research of the University of Freiburg, Germany.

1 Neumann HP, Lips CJ, Hsia YE, et al. Von Hippel-Lindau syndrome. Brain Pathol 1995;5:181-93.

2 Latif F, Tory K, Gnarra J, et al. Identification of the von Hippel-Lindau disease tumour suppressor gene. Science 1993;260:1317-20

3 Stolle C, Glenn G, Zbar B, et al. Improved detection of germline mutations in the von Hippel-Lindau disease tumour suppressor gene. Hum Mutat 1998;12:417-23.

4 Maxwell PH, Wiesener MS, Chang GW, et al. The tumour suppressor protein VHL targets hypoxia-inducible factors
for oxygen-dependent proteolysis. Nature 1999;399:271-5.

5 Ohh M, Yauch RL, Lonergan KM, et al. The von Hippel-Lindau tumour suppressor protein is required for proper assembly of an extracellular fibronectin matrix. Mol Cell 1998;1:959-68.

6 Pause A, Lee S, Lonergan KM, et al. The von HippelLindau tumour suppressor gene is required for cell cycle Lindau tumour suppressor gene is required for cell cycle
exit upon serum withdrawal. Proc Natl Acad Sci U S A exit upon serum

7 Ivanov SV, Kuzmin I, Wei MH, et al. Down-regulation of transmembrane carbonic anhydrases in renal cell carcinoma cell lines by wild-type von Hippel-Lindau transgenes. Proc Natl Acad Sci U S A 1998;95:12596-601.
8 Jones PA, Laird PW. Cancer epigenetics comes of age. Nat Genet 1999;21:163-7.

9 Baylin SB, Herman JG, Graff JR, et al. Alterations in DNA methylation: a fundamental aspect of neoplasia. Adv Cancer Res 1998;72:141-96.

10 Kanno H, Kondo K, Ito S, et al. Somatic mutations of the von Hippel-Lindau tumour suppressor gene in sporadic central nervous system hemangioblastomas. Cancer Res central nervous

11 Oberstrass J, Reifenberger G, Reifenberger J, et al. Mutation of the Von Hippel-Lindau tumour suppressor gene in capillary haemangioblastomas of the central nervous system. $\mathcal{F}$ Pathol 1996;179:151-6.

12 Tse JY, Wong JH, Lo KW, et al. Molecular genetic analysis of the von Hippel-Lindau disease tumour suppressor gene in familial and sporadic cerebellar hemangioblastomas. $A m \mathcal{F}$ Clin Pathol 1997;107:459-66.

13 Vortmeyer AO, Gnarra JR, Emmert-Buck MR, et al. von Hippel-Lindau gene deletion detected in the stromal cell component of a cerebellar hemangioblastoma associated with von Hippel-Lindau disease. Hum Pathol 1997;28:5403.

14 Lee JY, Dong SM, Park WS, et al. Loss of heterozygosity and somatic mutations of the VHL tumour suppressor gene in sporadic cerebellar hemangioblastomas. Cancer Res 1998; 58:504-8.

15 Crossey PA, Foster K, Richards FM, et al. Molecular genetic investigations of the mechanism of tumourigenesis in von Hippel-Lindau disease: analysis of allele loss in VHL tumours. Hum Genet 1994;93:53-8.

16 Prowse AH, Webster AR, Richards FM, et al. Somatic inactivation of the VHL gene in Von Hippel-Lindau disease tumours. Am f Hum Genet 1997;60:765-71.

17 Neumann HP. Basic criteria for clinical diagnosis and genetic counselling in von Hippel-Lindau syndrome. Vasa 1987;16:220-6.

18 Böhling T, Plate $\mathrm{KH}$, Haltia $\mathrm{M}$, et al. von Hippel-Lindau disease and capillary haemangioblastoma. In: Kleihues P, Cawenee WK, eds. Pathology and genetics of tumours of the nervous system. 2nd ed. Lyon: International Agency for Research on Cancer, World Health Organization, 2000;14: 223-6.

19 Sambrook J, Fritsch EF, Maniatis T. Molecular cloning. Cold Spring Harbor, NY: Cold Spring Harbor Laboratory Press, 1989.

20 Gnarra JR, Tory K, Weng Y, et al. Mutations of the VHL tumour suppressor gene in renal carcinoma. Nat Genet 1994;7:85-90.

21 Budowle B, Chakraborty R, Giusti AM, et al. Analysis of the VNTR locus D1S80 by the PCR followed by highresolution PAGE. Am f Hum Genet 1991;48:137-44.

22 Glavac D, Neumann HP, Wittke C, et al. Mutations in the VHL tumour suppressor gene and associated lesions in families with von Hippel-Lindau disease from central Europe. Hum Genet. 1996;98:271-80.

23 Jones $\mathrm{MH}$, Yamakawa K, Nakamura Y. Isolation and characterization of 19 dinucleotide repeat polymorphisms on chromosome 3p. Hum Mol Genet 1992;1:131-3.

24 Payne SJ, Richards FM, Maher ER. A PCR generated AccI RFLP in the 3' untranslated region of the von HippelLindau disease (VHL) tumour suppressor gene. Hum Mol Genet 1994;3:390.

25 Neumann HP, Bender BU. Genotype-phenotype correlations in von Hippel-Lindau disease. $\mathcal{f}$ Intern Med 1998;243:541-5.

26 Glasker S, Bender BU, Apel TW, et al. The impact of molecular genetic analysis of the VHL gene in patients with haemangioblastomas of the central nervous system. F Neurol Neurosurg Psychiatry 1999;67:758-62.

27 Clifford SC, Prowse AH, Affara NA, et al. Inactivation of the von Hippel-Lindau (VHL) tumour suppressor gene and allelic losses at chromosome arm $3 p$ in primary renal cell carcinoma: evidence for a VHL-independent pathway in clear cell renal tumourigenesis. Genes Chromosomes Cancer 1998;22:200-9.

28 Sekido Y, Bader S, Latif F, et al. Molecular analysis of the von Hippel-Lindau disease tumour suppressor gene in human lung cancer cell lines. Oncogene 1994;9:1599-604. 